\title{
Perbedaan Pengaruh Sevofluran dan Propofol Terhadap Kadar IL-6 dan Jumlah Neutrofil pada Operasi Kraniotomi
}

\section{The Effect of Sevoflurane and Propofol on IL-6 Level and Neutrophils in Craniotomy Surgery}

\author{
Bhimo Priambodo $^{\bowtie}$, Mohammad Sofyan Harahap, Taufik Eko Nugroho \\ Departemen Anestesiologi dan Terapi Intensif, Fakultas Kedokteran, Universitas Diponegoro/ \\ RSUP Dr. Kariadi, Semarang, Indonesia \\ ${ }^{\square}$ Korespondensi: bhimopriambodo@gmail.com
}

\begin{abstract}
Background: The innate immune system is the front line of defense and refers to the protective mechanism that existed prior to injury or infection. Component that can be assessed to acknowledge about immunity changes were cytokines (IL-6) and neutrophils. General anesthesia could be given using inhalation anesthesia, intravenous drug, or mostly in some cases, could be combination between them. All anesthesia drugs could modulate immune system and gave a certain effect to hereditary immunity.

Objective: This experiment study aimed to acknowledge the differences between sevoflurane and propofol effect towards immunity system as assessed by the level of IL-6 and neutrophils in neurosurgery.

Methods: This study used an experimental study method in 34 patients ( 17 patients sevoflurane group dan 17 patients propofol group) who underwent craniotomy that fulfills the inclusion criteria in this study. Group I (17 patients) was using sevoflurane 1 minimum alveolar concentration (MAC) and group II (17 patients) using propofol in maintenance infusion $100 \mu \mathrm{g} / \mathrm{KgBW} /$ minutes. Blood sampling was done to examination of IL-6 and neutrophils level before operation and two hours after incision. All data were analyzed statistically with Wilcoxon and Mann-Whitney test, considered significant if $p$ $<0,05$.
\end{abstract}

Results: From this study, we found that there was decreasing of neutrophils level in sevoflurane group around 0,02 $\pm 7,54 \%$ (insignificantly different, $p=0,205$ ) while in propofol group we found that there was increasing of neutrophils level around 5,07 \pm $7,01 \%$ (significantly different, $p=0,002$ ). In the comparative test between the two groups found a significant neutrophil levels difference $(p=0,002)$. The assessment of IL-6 levels showed in the sevoflurane group there was an increase of $4.86 \pm 6.87 \mathrm{pg} / \mathrm{ml}$ (significantly different $p=0.017$ ) and in the propofol group there was also an increase of $15.87 \pm 16.12 \mathrm{pg} / \mathrm{ml}$ (significantly different $p=<0.001$ ). In the comparative test the two groups found a significant IL-6 levels difference $(p=0.009)$

Conclusion: Sevoflurane suppressed IL-6 levels and neutrophil counts in craniotomy surgery.

Keywords: immunity; IL-6; neutrophils; sevoflurane; propofol 


\begin{abstract}
ABSTRAK
Latar Belakang: Imunitas bawaan adalah lini pertahanan pertama dan mengacu pada mekanisme perlindungan yang ada bahkan sebelum adanya luka / infeksi. Komponen yang dapat digunakan untuk mengetahui perubahan imunitas antara lain sitokin (IL-6) dan neutrofil. Anestesi umum dapat diberikan dengan menggunakan anestesi inhalasi, obat intravena, atau sebagian besar sering kombinasi keduanya. Semua bentuk obat anestesi ini dapat mempengaruhi sistem kekebalan tubuh dan memberikan efek pada imunitas bawaan.
\end{abstract}

Tujuan: Penelitian ini bertujuan untuk mengetahui perbedaan pengaruh sevofluran dan propofol terhadap sistem imun dinilai dari kadar IL-6 dan neutrofil pada operasi bedah saraf.

Metode: Dilakukan penelitian eksperimental terhadap 34 subjek (17 subjek kelompok sevofluran dan 17 subjek kelompok propofol) yang menjalani operasi kraniotomi yang memenuhi kriteria penelitian. Kelompok I (17 subjek) menggunakan sevofluran 1 minimum alveolar concentration (MAC) dan kelompok II (17 subjek) menggunakan propofol maintenance infusion $100 \mu \mathrm{g} / \mathrm{kg} / \mathrm{menit}$. Dilakukan pengambilan sampel darah untuk pemeriksaan kadar IL-6 dan neutrofil saat sebelum operasi dan 2 jam setelah insisi operasi. Data dianalisa secara statistik menggunakan Wilcoxon dan Mann-Whitney test, dianggap bermakna bila $\mathrm{p}<0,05$.

Hasil: Pada penelitian ini didapatkan penurunan kadar neutrofil pada kelompok sevofluran sebesar 0,02 \pm 7,54 \% dibanding kadar awal (berbeda tidak bermakna $\mathrm{p}=$ $0,205)$ sedangkan pada kelompok propofol didapatkan peningkatan kadar neutrofil sebesar 5,07 $\pm 7,01 \%$ dibanding kadar awal (berbeda bermakna $\mathrm{p}=0,002$ ). Pada perbandingan selisih kedua kelompok didapatkan perbedaan kadar neutrofil yang bermakna ( $\mathrm{p}=0,003)$. Kadar IL-6 pada kelompok sevofluran didapatkan peningkatan sebesar 4,86 $\pm 6,87 \mathrm{pg} / \mathrm{ml}$ dibanding kadar awal (berbeda bermakna $\mathrm{p}=0,017$ ) dan pada kelompok propofol juga didapatkan peningkatan sebesar 15,87 $\pm 16,12 \mathrm{pg} / \mathrm{ml}$ dibanding kadar awal (berbeda bermakna $\mathrm{p}=<0,001$ ). Pada perbandingan selisih kedua kelompok didapatkan perbedaan kadar IL-6 yang bermakna $(\mathrm{p}=0,009)$.

Kesimpulan: Sevofluran lebih menurunkan kadar IL-6 dan jumlah neutrofil dibandingkan dengan propofol pada operasi kraniotomi.

Kata Kunci: imunitas; IL-6; neutrofil; sevofluran; propofol 


\section{PENDAHULUAN}

Dalam beberapa dekade terakhir, bidang imunologi telah berkembang secara substansial, menjelaskan banyak mekanisme seluler dan molekuler yang mendasari kekebalan manusia. Sistem kekebalan mengenali dan menghilangkan patogen dengan bantuan respons imun bawaan dan respons imun adaptif. Imunitas bawaan, juga disebut kekebalan alami, adalah garis pertahanan pertama dan mengacu pada mekanisme perlindungan yang ada bahkan sebelum infeksi. Komponen utamanya adalah membran epitel (yang menghalangi masuknya patogen), sel fagosit (neutrofil dan makrofag), sel dendritik, natural killer cell (NK cell) dan beberapa protein plasma, termasuk sistem komplemen. Reaksi seluler yang paling penting dari imunitas bawaan adalah peradangan yang prosesnya dimediasi oleh sel-sel dendritik dan NK, di mana sel-sel fagositik direkrut dan diaktifkan untuk mengeliminasi patogen. ${ }^{1,2}$

Kekebalan adaptif, juga disebut kekebalan spesifik atau didapat, terdiri dari mekanisme yang diinduksi oleh pengenalan antigen patogen spesifik. Sistem imun adaptif dimediasi terutama oleh limfosit, dan fungsinya dapat diklasifikasikan menjadi dua jenis, yaitu imunitas humoral dan imunitas seluler. ${ }^{2}$

Obat anestesi dapat menekan respons imun dan dapat berlanjut menjadi alergi, infeksi, inflamasi, dan lain-lain. Anestesi umum dapat diberikan dengan menggunakan anestesi inhalasi, obat intravena, atau sebagian besar sering kombinasi keduanya. Semua bentuk obat anestesi ini dapat memodulasi sistem kekebalan tubuh dan memberikan efek pada kekebalan bawaan dan adaptif. ${ }^{3-8}$ Efek imunosupresif tersebut bergantung pada dosis dan lama waktu pemberian obat. Sebuah evaluasi secara komprehensif mengenai dampak obat anestesi pada sistem kekebalan tubuh dapat membantu memperbaiki pengelolaan perioperatif saat ini.

Sevofluran adalah generasi baru anestesi inhalasi yang telah banyak digunakan dalam praktik anestesi saat ini. Menurut Suter D et al, sevofluran memiliki efek tidak hanya menekan ekspresi mediator inflamasi seperti monocyte chemoattractant protein (MCP) -1, macrophage inflamatory protein (MIP) $1 \beta$, dan MIP-2, tetapi juga mengurangi adhesi neutrofil pada kerusakan sel epitel alveolar secara in vitro. ${ }^{9}$ Studi dari Kidani et al meneliti efek dari sevofluran terhadap tikus yang mengalami syok yang diinduksi endotoksin. Peneliti menemukan bahwa pemberian sevofluran secara signifikan meningkatkan tekanan darah sistolik, keseimbangan asam basa, dan menurunkan kadar plasma dari tumor necrosis factor (TNF)- $\alpha$ dan IL-6. ${ }^{10}$ Pada penelitian Cho EJ et al, sevofluran dapat menurunkan pelepasan sitokin, khusus IL-6, IL-8, dan IL-10, pada subjek yang menjalani operasi jantung. ${ }^{11}$ Namun di sisi lain, ada studi yang melibatkan sevofluran yang diberikan dalam konsentrasi 1,5 minimum alveolar concentration (MAC) selama lebih dari 2 jam menunjukkan peningkatan yang signifikan pada IL-1 $\beta$, MIP- 2, interferon- $\gamma$, dan TNF- $\alpha$ pada makrofag alveolar tikus di bawah ventilasi mekanis. $^{12}$

Propofol adalah salah satu obat anestesi yang memiliki mula kerja dan lama kerja yang relatif lebih singkat sehingga menjadi pilihan dalam anestesi modern baik untuk anestesi ataupun terapi pemeliharaan. Propofol mengurangi produksi sitokin proinflamasi, mengubah ekspresi nitrat oksida, dan menghambat fungsi neutrofil. ${ }^{13}$ Sebuah 
studi in-vitro baru-baru ini menunjukkan bahwa propofol hampir sepenuhnya menghambat aktivasi mikroglia yang diinduksi lipopolisakarida dan produksi sitokin proinflamasi. ${ }^{14}$ Di sisi lain, penelitian Pirttikangas et al menyatakan bahwa terdapat peningkatan IL-6 yang signifikan pada anestesi dengan pemberian propofol pada subjek yang menjalani operasi histerektomi perabdominal. ${ }^{15}$

Kraniotomi merupakan tindakan bedah yang paling sering dilakukan pada manajemen neoplasma primer dan metastasis neoplasma pada otak. Nyeri pembedahan sedikitnya mengalami dua perubahan, pertama akibat pembedahan itu sendiri yang menyebabkan rangsangan nosiseptif dan yang kedua setelah proses pembedahan terjadi respons inflamasi pada daerah sekitar operasi, dimana terjadi pelepasan mediator seperti prostaglandin, bradikinin, serotonin, substansi $\mathrm{P}$, dan histamin oleh jaringan yang rusak dan sel-sel inflamasi. ${ }^{16}$

IL-6 merupakan salah satu sitokin yang muncul awal dan merupakan mediator induksi dan kontrol pada sintesis protein fase akut yang dilepaskan oleh hepatosit selama stimuli nyeri seperti trauma, infeksi, operasi, dan luka bakar. ${ }^{16}$ Neutrofil merupakan salah satu sel granulosit yang memainkan peranan penting dalam pertahanan tubuh dan sel inflamasi yang paling awal menginfiltrasi jaringan yang mengalami trauma atau kerusakan dengan waktu paruh 4-10 jam. Menurut penelitian Muller-Edenborn B et al, Anestesi volatil dapat mengurangi respons inflamasi neutrofil dengan mengganggu pensinyalan reseptor-2 CXC. ${ }^{17}$

Penelitian dilakukan karena adanya data yang tidak konsisten serta obat anestesi sevofluran dan propofol sering digunakan dalam pembiusan sehari hari. Penelitian ini didesain untuk mengetahui perbedaan pengaruh sevofluran dan propofol terhadap sistem imun dinilai dari kadar IL-6 dan neutrofil pada operasi bedah saraf.

\section{METODE}

Rancangan penelitian ini adalah studi eksperimental dengan menggunakan pre dan post test. Sevofluran dan propofol diberikan selama 2 jam. Setelah itu diperiksa kadar IL-6 dan jumlah neutrofil dari sampel yang didapat. Sampel penelitian diambil dari subjek yang menjalani operasi kraniotomi di instalasi bedah sentral (IBS) RSUP Dr. Kariadi Semarang bulan Desember 2019 - Januari 2020 yang memenuhi kriteria inklusi dan ekslusi penelitian. Kriteria inklusi : (1) menjalani pembedahan elektif kraniotomi tumor; (2) Physical status American Society of Anesthesiologist (ASA) 1-2; (3) Usia 2555 tahun; (4) glasgow coma scale (GCS) 15; (5) subjek tidak memiliki penyakit pada sistem endokrin dan infeksi. Kriteria ekslusi : (1) subjek memiliki riwayat hipersensitivitas obat; (2) operasi kurang dari 2 jam; (3) adanya peningkatan tekanan intrakranial (TIK).

Teknik sampling menggunakan metode consecutive sampling. Didapatkan total sampel yang sebanyak 17 subjek tiap kelompok. Sampel dikelompokkan menjadi 2 kelompok perlakuan : kelompok 1 ( $\mathrm{K}$ 1) mendapat obat anestesi sevofluran dan kelompok 2 (K 2) mendapat obat anestesi propofol.

Di ruang operasi, subjek dipasang kateter arteri yang ditempatkan di arteri radial untuk pemantauan tekanan darah secara terus menerus. Pengambilan sampel darah untuk pemeriksaan kadar neutrofil dan interleukin-6 dilakukan 
langsung setelah kateter arteri terpasang. Subjek diberi premedikasi dengan midazolam $0,1 \mathrm{mg} / \mathrm{kg}$ intrvena (i.v.) Kedua kelompok subjek diinduksi dengan propofol $2 \mathrm{mg} / \mathrm{kg}$ dan sevofluran $2 \%$. Sebelum intubasi semua subjek menerima fentanil $2 \mu \mathrm{g} / \mathrm{kg}$ dan rocuronium $1 \mathrm{mg} / \mathrm{kg}$. Setelah intubasi, kedua kelompok diberi ventilasi mekanis dengan campuran oksigen-udara dan dengan rasio I / E 1: 2. Tingkat pernapasan disesuaikan untuk mempertahankan normal nilai paCO2 (tekanan parsial karbon dioksida di arteri darah). Volume tidal diatur ke $8 \mathrm{ml} / \mathrm{kg}$. Tekanan puncak inspirasi terbatas pada $35 \mathrm{~cm} \mathrm{H2O}$. Anestesi dipertahankan dengan propofol maintenance infusion $100 \mu \mathrm{g} / \mathrm{kg} / \mathrm{menit}$ pada kelompok propofol dan dengan sevofluran $1 \mathrm{MAC}$ dalam kelompok sevofluran. Fentanil disesuaikan sesuai dengan tingkat manipulasi bedah $(2 \mu \mathrm{g} / \mathrm{kg})$ dan diberikan jika tekanan arteri dan detak jantung meningkat lebih banyak dari $30 \%$ dari baseline. Parameter hemodinamik dicatat terus menerus dengan interval 5 menit dari awal induksi sampai keluar kamar operasi. Sevofluran dan infus propofol dihentikan di jahitan kulit terakhir. Dua jam setelah operasi dimulai, dilakukan pengambilan sampel darah untuk pemeriksaan kadar neutrofil dan IL-6.

\section{HASIL}

Sejumlah 34 subjek memenuhi kriteria inklusi dan memberikan persetujuan untuk mengikuti penelitian ini, dan keseluruhannya dibagi ke dalam dua kelompok. Kelompok pertama terdiri dari 17 subjek yang mendapatkan sevofluran dan kelompok kedua terdiri dari 17 subjek yang mendapatkan propofol (Tabel 1).

Pada kelompok sevofluran kadar neutrofil pada subjek mengalami penurunan dari $80,26 \pm 13,57 \%$ menjadi $80,24 \pm 11,61 \%(\mathrm{p}=0.205)$ sedangkan pada kelompok propofol kadar neutrofil mengalami peningkatan dari $81,29 \pm$ $10,81 \%$ menjadi $86,36 \pm 8,53 \%$ $(\mathrm{p}=0,002)$. Pada perbandingan selisih kedua kelompok dinilai dari kadar neutrofil didapatkan perbedaan yang bermakna $(p=0,003)$ (Tabel 2).

Untuk kadar IL-6, pada kelompok sevofluran didapatkan peningkatan sebesar 4,86 $\pm 6,87 \mathrm{pg} / \mathrm{ml}$ (berbeda bermakna $\mathrm{p}=0,017$ ) dan pada kelompok propofol juga didapatkan peningkatan sebesar 15,87 $\pm 16,12 \mathrm{pg} / \mathrm{ml}$ (berbeda bermakna $\mathrm{p}=<0,001)$. Pada perbedaan selisih kedua kelompok dinilai dari kadar IL-6 didapatkan perbedaan yang bermakna ( $\mathrm{p}=0,009)$ (Tabel 3).

Tabel 1. Karakteristik penelitian

\begin{tabular}{ccccc}
\hline Variabel & F & $\%$ & Mean \pm SD & Median $($ min - max $)$ \\
\hline Kelompok & & & & \\
Sevofluran & 17 & 50,0 & & \\
Propofol & 17 & 50,0 & & \\
Jenis kelamin & & & & \\
Laki-laki & 10 & 29,4 & & $44(34-55)$ \\
Perempuan & 24 & 70,6 & & \\
Usia (tahun) & & & $44,41 \pm 5,67$ & \\
ASA & & & & $84,1(49,8-95)$ \\
1 & 7 & 20,6 & & $2,48(0,61-64,8)$ \\
2 & 27 & 79,4 & $80,78 \pm 12,09$ & \\
Neutrofil (\%) pre & & & $6,26 \pm 12,26$ & \\
IL-6 (pg/ml) pre & & & &
\end{tabular}

Volume 13, Nomor 3, Tahun 2021 
Tabel 2. Perbedaan jumlah neutrofil (\%) berdasarkan sevofluran dan propofol

\begin{tabular}{lccc}
\hline \multirow{2}{*}{ Neutrofil (\%) } & \multicolumn{2}{c}{ Kelompok } & \multirow{2}{*}{$\mathrm{P}$} \\
\cline { 2 - 3 } Pre & Sevofluran & Propofol & $0,931^{\ddagger}$ \\
Post & $80,26 \pm 13,57$ & $81,29 \pm 10,81$ & $0,113^{\ddagger}$ \\
\hline \multicolumn{1}{c}{$\mathrm{P}$} & $80,24 \pm 11,61$ & $86,36 \pm 8,53$ & \\
\hline Selisih & $0,205^{\dagger}$ & $0,002^{\dagger *}$ & $0,003^{* *}$ \\
\hline
\end{tabular}

Keterangan: * Signifikan (p < 0,05); ${ }^{\ddagger}$ Mann whitney; ${ }^{\dagger}$ Wilcoxon

Tabel 3. Perbedaan kadar IL-6 berdasarkan sevofluran dan propofol

\begin{tabular}{lccc}
\hline \multirow{2}{*}{ IL-6 $(\mathrm{pg} / \mathrm{ml})$} & \multicolumn{2}{c}{ Kelompok } & \multirow{2}{*}{$\mathrm{P}$} \\
\cline { 2 - 3 } & Sevofluran & Propofol & $0,469^{\ddagger}$ \\
Pre & $3,64 \pm 3,97$ & $8,89 \pm 16,72$ & $0,007^{\ddagger *}$ \\
\hline Post & $8,50 \pm 5,71$ & $24,75 \pm 27,59$ & \\
\hline \multicolumn{1}{c}{$\mathrm{p}$} & $0,017^{\dagger *}$ & $<0,001^{\dagger *}$ \\
\hline Selisih & $4,86 \pm 6,87$ & $15,87 \pm 16,12$ & $0,009^{\ddagger *}$ \\
\hline
\end{tabular}

Keterangan: * Signifikan $(\mathrm{p}<0,05) ;{ }^{\ddagger}$ Mann whitney; ${ }^{\dagger}$ Wilcoxon

\section{PEMBAHASAN}

Terdapat perbedaan yang bermakna antara pemberian sevofluran dibandingkan dengan propofol terhadap sistem imun dinilai dari kadar IL-6 dan neutrofil pada operasi bedah saraf dimana sevofluran lebih menekan sistem imun dibandingkan dengan propofol. Hal ini sesuai dengan apa yang diharapkan dari penelitian ini.

Pada pemeriksaan neutrofil didapatkan kelompok sevofluran sebelum perlakuan dan sesudah perlakuan menunjukkan perbedaan yang tidak bermakna ( $\mathrm{p}=0,205)$ sedangkan pada kelompok propofol sebelum perlakuan dan sesudah perlakuan menunjukkan perbedaan yang bermakna $(p=0,002)$. Selisih jumlah neutrofil pada kedua kelompok dianalisis dengan uji komparatif Mann Whitney, dengan hasil menunjukkan perbedaan yang bermakna $(\mathrm{p}=0,003)$. Hal ini sesuai dengan penelitian MullerEdenborn B et al, dimana menyatakan sevofluran dapat mengurangi respons inflamasi neutrofil dengan mengganggu pensinyalan reseptor-2 CXC. ${ }^{17}$
Proses inflamasi merupakan bagian dari respons imun. Inflamasi sendiri merupakan respons tubuh terhadap kerusakan jaringan / invasi asing/ keduanya. Jaringan yang rusak akan dianggap asing oleh sistem imun. Mekanisme ini hanya diperlukan dalam kondisi tertentu dalam waktu yang tidak lama. Misalnya ketika suatu bagian tubuh mengalami luka terbuka, mekanisme inflamasi akan membantu menghilangkan sel yang rusak dan mempercepat proses penyembuhan. Sebaliknya, saat inflamasi terjadi dalam waktu yang lebih lama dari yang dibutuhkan, hal tersebut cenderung bersifat merugikan.

Pada penelitian ini, jumlah neutrofil lebih ditekan pada pemberian agen inhalasi sevofluran dibandingkan dengan pemberian propofol, padahal neutrofil dibutuhkan untuk penyembuhan luka. Pemakaian sevofluran dapat mengaktivasi adhesi leukosit dengan sel endotel pembuluh darah, dimana terjadi penurunan NADPH oksidase. 
NADPH merupakan sistem neutrofil yang memproduksi peroxide dan anion superoxide yang dibutuhkan dalam bacterial killing. Peroxide dan anion superoxide disamping dibutuhkan untuk fungsi neutrofil sebagai bacterial killing, juga dibutuhkan untuk mencegah marginasi dan adhesi leukosit dengan endotel pembuluh darah. Sehingga penekanan terhadap produksi substan ini (oleh agent inhalasi anestesi) akan mempermudah marginasi dan adhesi leukosit dengan endotel pembuluh darah. ${ }^{17}$

Pada penelitian Morisaki et al menyatakan bahwa pada studi manusia, sevofluran 2 MAC dapat menginduksi perubahan jumlah leukosit, tetapi menurunkan jumlah neutrofil dalam sampel darah tepi. pada penelitian ini menggunakan konsentrasi 1 MAC sevofluran pada operasi kraniotomi.

Pada pemeriksaan kadar IL-6 didapatkan kelompok sevofluran sebelum perlakuan dan sesudah perlakuan menunjukkan perbedaan yang bermakna $(\mathrm{p}=0,017)$ dan pada kelompok propofol sebelum perlakuan dan sesudah perlakuan juga menunjukkan perbedaan yang bermakna $(\mathrm{p}=<0,001)$. Selisih kadar IL-6 pada kedua kelompok dianalisis dengan uji komparatif Mann Whitney, dengan hasil menunjukkan perbedaan yang bermakna $(\mathrm{p}=0,009)$. Hal ini sesuai dengan penelitian Pirttikangas et al yang menyatakan bahwa terdapat peningkatan IL-6 yang signifikan pada anestesi dengan pemberian propofol pada subjek yang menjalani operasi histerektomi perabdominal. ${ }^{15}$

Sitokin berperan pada jalur utama dari respons inflamasi terhadap trauma pembedahan, mempunyai efek dalam memediasi dan mempertahankan respons inflamasi terhadap kerusakan jaringan dan juga menginisiasi perubahan sistemik yang terjadi. Setelah pembedahan mayor, sitokin utama yang akan dilepas adalah tumor necrosis factor- $\alpha$ (TNF- $\alpha)$, IL-1, dan IL-6. Inisial reaksi ditunjukkan dengan dilepasnya IL-1 dan TNF- $\alpha$ yang diaktivasi oleh makrofag dan monosit pada kerusakan jaringan. Proses ini menstimulasi produksi dan pelepasan sitokin lain, khususnya IL-6. Pada penelitian ini, kadar IL-6 sama-sama naik baik kelompok sevofluran ataupun propofol, namun pada kelompok propofol kenaikan kadar IL-6 sangat signifikan dimana IL-6 merupakan sitokin yang berperan dalam proses inflamasi.

Pada penelitian Cho EJ et al, sevofluran dapat menurunkan pelepasan sitokin, khusus IL-6, IL-8, dan IL-10, pada subjek yang menjalani operasi jantung. ${ }^{11}$ Pada penelitian ini, sampel diambil dari subjek dengan operasi kraniotomi. Baik kelompok sevofluran maupun kelompok propofol sama-sama mengalami kenaikan kadar IL-6, namun pada kelompok sevofluran hanya mengalami sedikit kenaikan kadar IL-6 dibandingkan kelompok propofol.

IL-6 dan neutrofil pada bahasan disini melambangkan proses inflamasi pada sistem imun bawaan atau alami yang merupakan garis pertahanan pertama dan merujuk pada mekanisme perlindungan yang ada saat terjadi perlukaan. Dalam 30-60 menit setelah pembedahan dimulai, konsentrasi IL-6 akan meningkat dan perubahan konsentrasi menjadi signifikan setelah 2-4 jam. Setelah pembedahan berlangsung, perubahan konsentrasi sitokin akan maksimal pada 24 jam pertama dan menetap pada 48-72 jam setelah pembedahan. Di jaringan sasaran, neutrofil aktif mematikan dan menghancurkan mikroba. Jumlahnya 
meningkat cepat dan mencapai puncaknya dalam $24-48$ jam. Bila tidak terjadi infeksi, neutrofil berumur pendek dan jumlahnya menurun dengan cepat setelah hari ke-3.

Dapat dilakukan penelitian lebih lanjut dari penelitian yang telah dilakukan ini dimana dapat diperiksa menggunakan marker sistem imun yang lain misalnya marker dari kelompok sistem imun adaptif atau sistem imun spesifik (immunoglobulin, T helper 1, T helper 2, dll). Sevofluran masih bisa digunakan untuk pembiusan karena hanya mempengaruhi proses inflamasi, dimana inflamasi hanya merupakan salah satu respons imun bawaan. Masih banyak faktor yang dapat mempengaruhi sistem imun selain inflamasi.

\section{KESIMPULAN}

Sevofluran lebih menurunkan kadar IL-6 dan jumlah neutrofil dibandingkan dengan propofol pada operasi kraniotomi.

\section{DAFTAR PUSTAKA}

1. Satpathy AT, Wu X, Albring JC, Murphy KM: Re(de)fining the dendritic cell lineage. Nat Immunol 2012; 13:1145-54

2. Iwasaki A, Medzhitov R: Control of adaptive immunity by the innate immune system. Nat Immunol 2015; 16:343-53

3. Schneemilch CE, Hachenberg T, Ansorge S, Ittenson A, Bank U: Effects of different anaesthetic agents on immune cell function in vitro. Eur $\mathrm{J}$ Anaesthesiol 2005; 22:616-23

4. Homburger JA, Meiler SE: Anesthesia drugs, immunity, and long-term outcome. Curr Opin Anaesthesiol 2006; 19:423-8

5. Kurosawa S, Kato M: Anesthetics, immune cells, and immune responses. J Anesth 2008; 22:26377

6. Pirbudak CL, Ugur MG, Karadasli $\mathrm{H}$ : Comparison of effects of lowflow sevoflurane and desflurane anesthesia on neutrophil and T-cell populations. Curr Ther Res Clin Exp 2012; 73:41-51

7. Gong L, Qin Q, Zhou L, Ouyang W, $\mathrm{Li} \mathrm{Y}, \mathrm{Wu} \mathrm{Y}, \mathrm{Li} \mathrm{Y}$ : Effects of fentanyl anesthesia and sufentanil anesthesia on regulatory $\mathrm{T}$ cells frequencies. Int $\mathrm{J}$ Clin Exp Pathol 2014; 7:7708-16

8. Alsina E, Matute E, Ruiz-Huerta AD, Gilsanz F: The effects of sevoflurane or remifentanil on the stress response to surgical stimulus. Curr Pharm Des 2014; 20:5449-68

9. Suter D, Spahn DR, Blumenthal S, Reyes L, Booy C, Beck-schimmer B : The Immunomodulatory effect of Sevoflurane in Endotoxin-injured alveolar epithelial cells. Anesth Analg. 2007;104:638-645

10. Kidani Y, Taniguchi T, Kanakura H, Takemoto Y, Tsuda K, Yamamoto $\mathrm{K}$, Sevoflurane pretreatment inhibits endotoxin-induced shock in rats. Anesth Analg. 2005;101:1152-1156

11. . EJ, Yoon JH, Hong SJ, Lee SH, Sim SB: The effects of sevoflurane on systemic and pulmonary inflammatory responses after cardiopulmonary bypass. J Cardiothorac Vasc Anesth 2009; 23:639-45

12. Kotani N, Takahashi S, Sessler DI, Hashiba E, Kubota T, Hashimoto H, Matsuki A: Volatile anesthetics augment expression of proinflammatory cytokines in rat alveolar macrophages during mechanical ventilation. Anesthesiology 1999; 91:187-97

13. Marik PE. Propofol: an immunomodulating agent. 
Pharmacotherapy. 2005;25(5 Pt 2):28-33S.

14. Ye $\mathrm{X}$, Lian $\mathrm{Q}$, Eckenhoff $\mathrm{MF}$, Eckenhoff RG, Pan JZ. Differential general anesthetic effects on microglial cytokine expression. PLoS One. 2013 ;8(1): e52887.

15. Yang SC, Chung PJ, Ho CM, Kuo CY, Hung MF, Huang YT, Chang WY, Chang YW, Chan KH, Hwang TL. Propofol inhibits superoxide production, elastase release, and chemotaxis in formyl peptideactivated human neutrophils by blocking formyl peptide receptor 1 . J Immunol. 2013;190:6511-19.

16. Jun-hua, Z. \& Yu-guang, $H$. Immune system: a new look at pain. Chin Med J, 2006. 119, 930-938.

17. Müller-Edenborn B, RothZ'Graggen B, Schlicker A, Reyes L, Booy C, Hasler M, Stark WJ, BeckSchimmer B: Fluorinated groups mediate the immunomodulatory effects of volatile anesthetics in acute cell injury. Am J Respir Cell Mol Biol 2011, 45:617-624 